\title{
Shalom \& Eirene: Fully Caring for the Afflicted Person
}

\section{Apolos Landa}

${ }^{\text {a } M D, ~ M S c ~ C H D C ~ o f ~ L S H T M ~, ~ M T h ~ R e g i o n a l ~ C o o r d i n a t o r ~ f o r ~ S o u t h ~ A m e r i c a, ~ L u k e ~ S o c i e t y, ~ M o y o b a m b a, ~ P E R U ~}$

The biblical concepts and categories relating to the person portray the individual as a multidimensional relational totality. To be fully human is to be a constitutive part of the whole creation in an enhancing relationship with God, with others made in his image and likeness, and with the rest of God's creation. The ecosystem, cultureeducation, family, and friends unavoidably influence the individual, as do the choices he or she has already made. Thus to be "a responsible partner" with God in the creative process of becoming and making shalom, a person needs to be selfreconciled and then become reconciled one with another, in family, in community, and in all other spheres of their immediate and cosmic context. It is this that proves a person to be truly reconciled with God and thus enables him or her to become fully human.

The creation narratives give us an understanding of what God's ideal is for human wholeness in regard to physical and social health. In Genesis 1 and 2, God's creative project is pronounced good and finished, up to the stage at which humanity had been created. From there, male and female, as a human partnership, are commanded to subdue and rule the creation and the powers of creation with a view to the fullness of God's cosmic intention, even in the aftermath of the fall. ${ }^{1} \quad$ Yet, due to disobedience and rebellion, there is a dramatic failure and the task of establishing shalom (שָלָ)), health and wholeness remains far from being completed.

The good news is that God has not given up on his creation. In the Pentateuch (Torah), we gain understanding of how God chooses and calls from fallen humanity those with whom he will work. Moreover, God restores and saves, pre- pares, and involves this people in his ongoing quest to bring back his humanity and creation to completion. Goldingay agrees with Juergen Moltmann and concludes that "Genesis does recognize that creation was the beginning of a project, not the end of one." In fact, he goes further, asserting that

. . . the statement that God's relationship with the world involves "creation, conservation, and transformation" does not say quite enough. Even before it went wrong and needed restoration, it was a project still on the way ... God would hardly have given humanity the task not merely of maintaining it but of subduing the world. So the renewed world is not merely a world restored to its Edenic state, but one taken to the destiny God intended when creating it. God's creation commission was that humanity should subdue the earth (Gen 1:28), win it to the internal harmony that was apparently not built into it even though it could be described as "good," and God is still committed to the fulfilling of that creation project. There will come a day [as Isaiah 11 and 65 envisions, in which there will be total harmony] ... without human beings or animals eating one another [and that] is part of the dream vision of Genesis 1, of a world that reflects Yhvh's abode in heaven ... a new creation in which the great limitation of the old, the reality of death, is overcome. ${ }^{2}$

Paul Tillich calls this process "cosmic healing" and states that "when salvation has cosmic significance, healing is not only included in it, but salvation can be described as the act of cosmic healing." In a person, the cosmos converges and 
is united, and, therefore, in a person, it has to be reconciled, healed, saved, and subjected again. $\mathrm{He}$ says:

[Not to see salvation and healing related] ... . implies a conscious or unconscious rejection of the idea of cosmic disease, the universal fall, and of cosmic healing, the universal redemption. It does not see that the eternal fulfilment is actual in the fragmentary fulfilment in time and space. Healing as well as salvation are temporal and, at the same time, are eternal. Healing acquires the significance of the eternal, and salvation the actuality of the temporal. ${ }^{3}$

The New Testament Greek Lexicon and the Nuevo Diccionario Bíblico Español Certeza (NDBC) informs us that the meaning of healing is closely related to salvation, as the meaning of the Greek word soteria, sozo (to save, to heal) in the NT parallels the meaning of the Hebrew yasha' (from which the words moshiah-messiah and $\mathrm{Ye}$ shua-Jesus derive) in the OT. ${ }^{4}$ This Hebrew verb, according to The Old Testament Hebrew Lexicon, means to save, be saved, and be delivered. Salvation, known as the Greek word soteria, is merely a derivative noun from sozo, which is the verb form, and derives in turn from a primitive sos (contracted for the now obsolete word saos, "safe"). It has also been found that the root of the word "salvation" in many languages indicates healing, as Paul Tillich illustrates:

Thus, the Greek word soteria is derived from saos (sic); the Latin word salvatio from salvus; the German word Heiland from heil, which is akin to the English word "healing." Saos, salvus, heil, mean whole, not yet split, not disrupted, not disintegrated, and therefore healthy and sane ... the English translation of sesoken se ["has saved thee," referring to an act of healing by Jesus in Mat 9:12] reads: "made thee whole." Salvation is basically and essentially healing, the re-establishment of a whole that was broken, disrupted, disintegrated . ${ }^{3}$

Both, in the Bible and in the mythological narrative of many non-biblical witnesses, Tillich finds a basis for saying that salvation, in the sense of making whole or healing, equally applies to the physical, psychological, and social dimensions of human life. He explains that

... every specific state of health or salvation represents the cosmic wholeness in a being which is a fragment of the whole, and whose wholeness is, therefore, always conditioned, threatened, imperfect, and pointing beyond itself. ${ }^{3}$

A vision of the kingdom of God is a vision of a creation brought to wholeness, that is, to a state of shalom (שָׁi). It is also a vision of a society in which the values of justice, peace, and joy in relationship prevail without exclusion. Therefore, healing also "involves a struggle against injustice by making the necessary resources available to the poor," the agents of healing -themselves risking poverty. ${ }^{5}$ This is the attitude in which the mission for salvation or healing must be forwarded in the world.

The journey towards shalom and wholeness includes pain and suffering. These are not realities that can be ignored. Health is not simply the absence of illness. If it were so, then the chronically sick, the disabled, and the frail elderly would be discounted from a healthy society, a reality which, though unacceptable and reproachable, is never far away in our Western lifestyle. Therefore, there is no guarantee that the healing agents will not be wounded in the process of fulfilling their mission. The recent experience of many health agents both secular and religious with Ebola epidemics in Liberia speaks a great deal about this. Sometimes, the healing that deals also with values and relationships includes breaking, wounding, and even permanent scars for those seeking healing and wholeness. As in the case of Jacob, after healing his relationship with his brother Esau, he walks away to a full life with a conquered blessing from God, with a dignifying new name, but with a permanent limp. Thus, for caring and healing, Tillich concludes:

This is the function of reconciliation, to make whole the man who struggles against himself. It reaches the centre of personality, and unites man not only with his God and with himself, but also with other men and 
nature. Reconciliation in the centre of personality results in reconciliation in all directions, and he who is reconciled is able to love. Salvation is the healing of the cosmic disease which prevents love. ${ }^{3}$

Such are the powerful values and insights

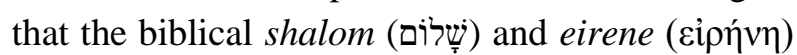
shed for our health care concerns and practices of today. To recover them provides reasons to reject the "patent-evergreening", free-market deformation of pharmaceutical, medical, and health developments $^{7}$ for commercial profit. ${ }^{8}$ Conversely, it provides reasons to equally reject the abuse of users and beneficiaries of the blessings of health and care by running senseless risks, by carelessness, and by negligence that overload the health systems unnecessarily, revealing no personal or collective concern for those in real need. ${ }^{9}$ It leads also to the rejection of all egotism in people, companies, and states that impose endeavours with negative impacts for nature, society, and life.

Anything less than an integrated approach to health and healing in the search for wholeness for the human person and creation will result in mere patchwork efforts and disillusionment. It can also wound and corrupt the healers. As those in mission, sent to heal in the comprehensive approach of God's intention, healers need to rediscover the biblical view of the person, as well as of health and healing.

\section{References}

1. Gen. 1:26, 28c; Psalms 8:3-8; Heb. 2:6-9.

2. Goldingay J. Old Testament theology: Israel's faith, Vol. 2. Downers Grove, Illinois: IVP Academic; 2006. [p.728-9]

3. Tillich P. The Meaning of Health. The Relation of Religion and Health Historical Considerations and Theoretical Questions. In Palmer M, editor. Writings in the Philosophy of Culture, Vol 2. New York: Walter de Gruyter \& Co.;1990. [p 211-6]

4. Bruce FF, Marshall IH, Millard AR, Packer JI, Wiseman DJ, Powell DR. El Nuevo Diccionario Bíblico Certeza, 2nd ed. Buenos Aires: Ediciones Certeza Unida; 2003. [1220 p.] [author's free translations]

5. Allen EA. The Church's Ministry of Healing: The Challenges to Commitment. In Allen EA, Luscombe K, Myers BL, et al, editors. Health, Healing and Transformation. California: MARK/World Vision International; 1991. [p 23]

6. A full new patent for the same slightly modified product, to avoid patent expiration, and to extend profiting monopoly for the pharmaceutical products at the expense of excluding generic drugs from the market.

7. Mudur G. MSF challenges Novartis's action over Indian patent for Imatinib. Brit Med J. 2007; 334: 172. http://dx.doi.org/10.1136/bmj.39104.718380.AB

8. Blech J. Inventing Diseases and Pushing Pills: Pharmaceutical Companies and the Medicalization of Normal Life. New York: Routledge; 2006. [p 17, 21-3, 66-8]

9. Lessig L. Free Culture: How Big Media Uses Technology and Law to Lock Down Culture and Control Creativity. NY: Penguin Press; 2004. [p 211-3]

This is Part Il of a two-part series.

Portions of this paper were previously published in the Lausanne World Pulse, February 2009 http://www.lausanneworldpulse.com/themedarticles.php/1090?pg=all

Competing Interests: None declared.

Correspondence: Dr. Apolos Landa. Luke Society, Moyobamba, PERU panluk@usa.net

Cite this article as: Landa, A. Shalom \& eirene: The full framework for health care. Christian Journal for Global Health (November 2014), 1(2):16-18. http://dx.doi.org/10.15566/cjgh.v1i2.39

(C) Landa, A. This is an open-access article distributed under the terms of the Creative Commons Attribution License, which permits unrestricted use, distribution, and reproduction in any medium, provided the original author and source are properly cited. To view a copy of the license, visit http://creativecommons.org/licenses/by/4.0/

www.cjgh.org

Nov 2014. Christian Journal for Global Health, 1(2):16-18. 